\title{
Seasonal variation in the biochemical composition of deep-sea nematodes: bioenergetic and methodological considerations
}

\author{
R. Danovaro ${ }^{1, *}$, A. Dell'Anno ${ }^{1}$, D. Martorano ${ }^{2}$, P. Parodi ${ }^{2}$, N. D. Marrale ${ }^{2}$, \\ M. Fabiano ${ }^{2}$ \\ ${ }^{1}$ Facoltà di Scienze, Università di Ancona, Via Brecce Bianche, I-60131 Ancona, Italy \\ ${ }^{2}$ Istituto Scienze Ambientali Marine, Università di Genova, Viale Benedetto XV, 5, I-16132 Genova, Italy
}

\begin{abstract}
Deep-sea nematode assemblages from one station (950 $\mathrm{m} \mathrm{depth}$ ) in the Cretan Sea (Eastern Mediterranean) were studied for seasonal variations in the gross biochemical composition. Seasonal changes in nematode composition were related to qualitative and quantitative changes in the sedimentary organic detritus and particle fluxes. Additional coastal sediment samples were collected to evaluate the effects of preservative ( $4 \%$ formalin) on biochemical determinations and to compare nematode body composition in coastal and deep-sea assemblages. Protein represented the major biochemical class of organic compounds in nematodes, accounting for 43.7 and $48.5 \%$ of organic matter con average 24 and $29 \%$ of dry weight [DW]) in coastal and deep-sea nematodes, respectively. Carbohydrate levels of nematodes (accounting on average for 8 and $26 \%$ of DW and for 16 and $40 \%$ of organic matter, respectively, in coastal and deep-sea nematodes) appeared to be rather high when compared to literature values dealing with other taxa. Carbohydrates were the dominant biochemical class both in the sediments and in particle fluxes. Body composition of nematodes revealed rather high lipid levels (on average 11 and $17 \%$ of DW and 16 and $35 \%$ of organic matter, respectively in coastal and deep-sea nematodes). Such discrepancy appears to indicate a different bioenergetic strategy by deep-sea organisms that develop efficient energy storage systems to be able to cope with long periods of very low food availability. Deep-sea nematode body weight decreased between February-March and September 1995 concomitantly with the decrease in particle flux. Coastal nematodes displayed higher individual biomass than the deep-sea ones $\left(0.44 \pm 0.06\right.$ vs $0.37 \pm 0.06 \mu \mathrm{g} \mathrm{DW}$ ind. ${ }^{-1}$, respectively), but were characterised by lower caloric values (5.57 vs $\left.6.68 \mathrm{cal} \mathrm{mg}^{-1} \mathrm{DW}\right)$. The caloric value of deep-sea nematodes was close to that of high-energy zooplankton, indicating that nematodes might represent an important high-quality food source for higher trophic levels. The reduced food inputs (especially carbohydrates and proteins) observed from February to September 1995 determined a parallel decrease in the concentration of sedimentary labile compounds and induced a clear decrease of the nematode energy content. However, no equally large seasonal changes in the total energy content (expressed as $\mathrm{J} \mathrm{m}^{-2}$ ) of the nematode assemblages were observed. We hypothesise that deep-sea nematodes might respond to diminished food inputs by changing their bioenergetic strategies to better exploit the available resources.
\end{abstract}

KEY WORDS: Nematodes - Body composition - Lipids · Proteins · Carbohydrates · Pelagic-benthic coupling

\section{INTRODUCTION}

Deep-sea meiobenthos has a biomass equivalent to or higher than that of macrobenthos (Tietjen 1992). Food availability is one of the most important factors regulating meiofaunal distribution and community

•E-mail: danovaro@popcsi.unian.it structure (Soyer 1985, Pickney \& Sandulli 1990, Riera et al. 1996). In such oligotrophic environments the nourishment of benthos is largely dependent on the particle rain from the euphotic layer, which varies widely in quantity and availability throughout the year (Christensen \& Kanneworff 1985, Lehtonen 1996) Meiofauna, due to their intermediate trophic position (Coull \& Bell 1979), can play a key role in the transfer 
of organic matter within the benthic food webs. Nematodes are the most represented metazoan component (Vincx et al. 1994, Montagna et al. 1995) and may constitute one of the major food sources for bentho-nekton assemblages including demersal fish and shrimps (Bell \& Coull 1978).

However, in spite of the quantitative importance in all marine environments, the trophic role of nematodes is not completely understood. Little is known about nematode biochemical composition and nutritional value (Soetaert \& Heip 1995), and no data are available on seasonal changes in the biochemical composition of nematodes in deep-sea environments. Previous studies on both planktonic (Bamstedt 1975 , 1978, Hopkins et al. 1993) and benthic organisms (Ansell 1974, Norbbin \& Bamstedt 1984, Miliou et al. 1992, Lehtonen 1996) have emphasised the influence of seasonal fluctuations in food availability and temperature on the biochemical composition, energy content and calorific value of marine invertebrates (Clarke 1977, Falk-Petersen 1981, Lehtonen 1996). As evident from the clear difference in the lipid content of their tissues, plankton and benthos appear to show different bioenergetic strategies related to different environmental constraints (Norbbin \& Bamstedt 1984, Clarke \& Peck 1991).

This study was carried out to test the hypothesis that the nutritional value of nematodes is controlled by changes in environmental conditions and, in particular, changes in the quality and quantity of food available to the benthos.

A problem generally related to the study of the biochemical composition of marine organisms is that biochemical determinations are carried out on fresh or freeze-dried material. This is unfortunate since meiofaunal samples are commonly preserved in buffered formalin (Higgins \& Thiel 1988). The possibility of carrying out biochemical analyses on formalin-preserved nematodes would be of great importance as there is a complete lack of information on their body composition and, consequently, their caloric content and quantitative role in the energy transfer through the benthic food webs.

The use of formalin as a preservative may cause serious analytical problems in the determination of certain classes of organic compounds (such as organic carbon) and nucleic acids in copepods (Saiz et al. 1998), but not in others (such as aminoacids and lipids). Wakeham et al. (1993), testing the effects of different treatments to preserve sediment trap samples demonstrated that, applying specific methodologies, the use of formalin as a preservative did not affect the determination of proteins, carbohydrates or lipids when compared to untreated samples. Similar results were obtained by Chronis et al. (1996) on preserved trap samples from the Cretan Sea, but the effects of formalin on the determination of the biochemical composition of nematodes have not been tested yet.

In this study we collected nematodes from coastal and deep-sea sediments in order to: (1) evaluate the effects of formalin on the determination of their biochemical composition; (2) compare the biochemical composition of coastal and deep-sea nematodes and (3) analyse changes in the biochemical composition of deep-sea nematodes in relation with seasonal fluctuations in food supply.

\section{MATERIALS AND METHODS}

Sampling of coastal sediments for comparison between fresh and preserved nematodes. Sediment samples were taken at Prelo $\left(44^{\circ} 20^{\prime} 00 \mathrm{~N}, 9^{\circ} 14^{\prime} 00 \mathrm{E}\right)$ (Ligurian Sea, NW Mediterranean Sea) in spring 1997. The study area is sheltered and characterised by the presence of a large Posidonia oceanica meadow (Danovaro 1996). Surface sediment samples (0 to $2 \mathrm{~cm}$ ) were collected at $1 \mathrm{~m}$ depth manually using a series of corers. In order to investigate the effects of the preservative (i.e. formalin) on nematode biochemical composition, sediment samples, to which prefiltered seawater had been added, were split into 2 aliquots of about 2 i; one was buffered (with sodium tetraborate $20 \mathrm{~g} \mathrm{l}^{-1}$ ) and preserved (formalin $4 \%$ final concentration) and the other was maintained at $4^{\circ} \mathrm{C}$ and rapidly brought to the laboratory. Immediately after sampling, living nematodes were extracted by decantation in prefiltered seawater and sieved through a $37 \mu \mathrm{m}$ mesh net. Nematodes preserved in formalin were extracted after a period of $4 \mathrm{wk}$. All samples were stained with Rose Bengal $\left(0.5 \mathrm{~g} \mathrm{l}^{-1}\right.$ stock solution, final concentration $0.5 \mu \mathrm{g} \mathrm{ml^{-1 }}$. After extraction, living nematodes were sorted under a stereo microscope (at $\times 40)$. At least 200 nematodes per replicate ( $n=3$ to 5 ) were placed on Whatman GF/F glass fibre filters previously treated in a muffle furnace $\left(450^{\circ} \mathrm{C}, 2 \mathrm{~h}\right)$, and stored at $-20^{\circ} \mathrm{C}$ until biochemical analyses were carried out. The same treatment was applied to the preserved nematodes.

Additional nematodes were withdrawn to determine the mean biomass of the individuals: at least 200 organisms per 3 replicates were placed on preweighed Whatman GF/F glass-fibre filters, and treated in a muffle furnace, $450^{\circ} \mathrm{C}$ for $2 \mathrm{~h}$. Nematode dry weight (DW) was determined gravimetrically, after drying the samples $\left(60^{\circ} \mathrm{C}, 24 \mathrm{~h}\right)$ to constant weight, using a Mettler M3 microbalance (accuracy $\pm 1 \mu \mathrm{g})$.

Nematode sampling in the deep Cretan Sea. Deepsea sediment samples $(950 \mathrm{~m})$ were collected in the 
Cretan Sea, north of the city of Iraklio $\left(35^{\circ} 17^{\prime} 34^{\prime \prime} \mathrm{N}\right.$, $24^{\circ} 25^{\prime} 71^{\prime \prime} \mathrm{E}$ ), on board the RV 'Philia', during August-September 1994, February-March 1995, May 1995 and September 1995. The study area is highly oligotrophic and characterised by low productivity (Ignatiades 1998). Four to 5 rephicate cores were taken at all sampling periods using a multicorer (diam. $9 \mathrm{~cm}, 63.6 \mathrm{~cm}^{2}$, for details see Danovaro et al. 1996). For the analysis of nematode abundance, biomass and biochemical composition, prefiltered seawater containing buffered formalin $(4 \%$ final concentration) was added to sediment samples and nematodes were extracted as described above. For each biochemical analysis (lipids, proteins and carbohydrates) and for each sampling occasion, at least 200 nematodes were collected in 3 to 5 replicates and placed on Whatman GF/F glass-fibre filters, previously treated in a muffle furnace $\left(450^{\circ} \mathrm{C}\right.$ for $\left.2 \mathrm{~h}\right)$, washed with prefiltered seawater and stored at $-20^{\circ} \mathrm{C}$ until analysis.

Nematode biochemical composition. All glassware utilised for the biochemical composition of nematodes was soaked in $1 \mathrm{M} \mathrm{NaOH}$ and subsequently rinsed with MilliQ water to avoid any organic contamination. In order to increase extraction efficiency, prior to all analyses, the filters containing the nematodes were homogenised in $1 \mathrm{ml}$ of MilliQ water and then sonicated for $2 \mathrm{~h}$ at $4^{\circ} \mathrm{C}$, frozen twice for $30 \mathrm{~min}\left(-20^{\circ} \mathrm{C}\right)$ and sonicated again for $10 \mathrm{~min}$ at $4^{\circ} \mathrm{C}$. All crude material placed on the filter (i.e. the entire homogenate) was utilised for each biochemical analysis separately. All biochemical analyses were carried out on the $1 \mathrm{ml}$ of homogenate. To determine the detection limits of the analyses, internal standards were added to replicate samples. The accuracy of the methods was tested against prepared standards obtained from dilution of $100 \mu \mathrm{g} \mathrm{m} \mathrm{m}^{-1}$ stock solution for proteins and carbohydrates, and of $40 \mathrm{\mu g} \mathrm{ml}^{-1}$ stock solution for lipids; final concentrations were $2.5,5,10,20 \mu \mathrm{g} \mathrm{ml}^{-1}$ for all standards utilised.

Lipid extraction was carried out according to Bligh \& Dyer (1959) by direct elution with chloroform and methanol $(1: 2 \mathrm{v}: \mathrm{v})$. The extracted lipids were then dried at $80^{\circ} \mathrm{C}$ (20 min) and determined spectrophotometrically after carbonisation at $180^{\circ} \mathrm{C}$ in concentrated sulphuric acid according to Marsh \& Weinstein (1966); tripalmitine solutions were used as standard. Various techniques are applicable for lipid analysis (Folch et al. 1957, Barnes \& Blackstock 1973), but the method of Marsh \& Weinstein (1966) was selected because of its capability to detect a large range of lipid species, and because of its adequate sensitivity and accuracy $( \pm 1.5 \mu \mathrm{g})$. Nematode protein concentration was determined according to Hartree (1972) using bovine albumin serum solution as standard. The determination of proteins based on folin-reacting peptides is carried out spectrophotometrically. Carbohydrates were analysed according to Gerchakov \& Hatcher (1972) and glucose solution was used as standard. The method is based on the same principles as the commonly used phenolsulphuric protocol of Dubois et al. (1956). In order to avoid the interference of formalin in carbohydrate analysis, filters were accurately rinsed with $10 \mathrm{ml}$ artificial seawater.

For each biochemical analysis, blanks were made using the same filters previously treated in a muffle furnace $\left(450^{\circ} \mathrm{C}, 2 \mathrm{~h}\right)$. To evaluate the possible interference of the preservative and stain on the biochemical analyses, additional blanks, on 3 replicates, were analysed after treatment with formalin solution $(4 \%)$, Rose Bengal (final concentration $0.5 \mu \mathrm{g} \mathrm{m}^{-1}$ ) and the combination of both. The blanks were then rinsed with prefiltered artificial seawater and processed as previously described for the other samples.

The individual nematode concentration of lipids, proteins and carbohydrates was obtained by dividing the total concentration of each biochemical compound by the number of nematodes placed in each filter. Organic matter of nematodes is referred to here as the sum of lipids, proteins and carbohydrates. Biochemical parameters were converted to energy equivalents as follows: lipids $=39.95 \mathrm{~J} \mathrm{mg}^{-1} \mathrm{DW}$, proteins $=23.63 \mathrm{~J} \mathrm{mg}^{-1} \mathrm{DW}$ and carbohydrates $=17.18 \mathrm{~J}$ $\mathrm{mg}^{-1}$ DW. The calorific value of nematodes was calculated using the Winberg (1971) equation as cal $\mathrm{mg}^{-1}=0.041 \times \%$ carbohydrates $+0.055 \times \%$ proteins $+0.095 \times \%$ lipids.

\section{RESULTS}

\section{Environmental parameters}

Data on sediment organic matter composition in the Cretan Sea have been summarised from Tselepides et al. (1996) and reported in Table 1. Sedimentary organic matter (OM) was characterised by the strong dominance of carbohydrates (range 515 to $7476 \mu \mathrm{g} \mathrm{g}^{-1}$, on average $76 \%$ of the sum of the 3 biochemical classes), followed by proteins ( 116 to $614 \mu \mathrm{g} \mathrm{g}^{-1}, 19 \%$ ) and lipids ( 47 to $55 \mathrm{\mu g} \mathrm{g}^{-1}, 5 \%$ ). OM concentrations displayed strong seasonal changes with highest values in August 1994 and lowest in September 1995. Seasonal changes in labile organic matter flux to the bottom have been summarised from (Chronis et al. 1996) and reported in Table 1 . The values reported have been integrated to the month prior to nematode collection. Data on sedimentation rates during August 1994 are not available since trap deployment started only in November 1994. 
Table 1. Sedimentary organic matter composition and particle fluxes at 35 mab in the Cretan Sea. Concentrations of proteins, carbohydrates and lipids in the deep-sea sediment $(0-1 \mathrm{~cm})$ as $\mu \mathrm{g} \mathrm{g}^{-1}$ dry weight and fluxes of particulate proteins (PRT), carbohydrates (CHO) and lipids (LIP) are reported

\begin{tabular}{|c|c|c|c|c|c|c|c|c|c|}
\hline \multirow[t]{2}{*}{ Sampling period } & \multicolumn{2}{|c|}{ Proteins } & \multicolumn{2}{|c|}{ Carbohydrates } & \multicolumn{2}{|c|}{ Lipids } & \multirow{2}{*}{$\begin{array}{c}\text { PRT } \\
\left(\mathrm{mg} \mathrm{m} \mathrm{m}^{-2} \mathrm{~d}^{-1}\right)\end{array}$} & \multirow{2}{*}{$\begin{array}{c}\mathrm{CHO} \\
\left(\mathrm{mg} \mathrm{m}^{-2} \mathrm{~d}^{-1}\right)\end{array}$} & \multirow{2}{*}{$\frac{\operatorname{LIP}}{\left(m g \mathrm{~m}^{-2} \mathrm{~d}^{-1}\right)}$} \\
\hline & $\left(\mu g^{-1}\right)$ & $\mathrm{SD}$ & $\left(\mu g g^{-1}\right)$ & $\mathrm{SD}$ & $\left(\mu g^{-1}\right)$ & $\mathrm{SD}$ & & & \\
\hline August 1994 & 205.4 & 107.0 & 7476.0 & 1101.5 & 154.9 & 42.3 & na & na & na \\
\hline February 1995 & 614.0 & 88.2 & 2563.7 & 575.1 & 84.7 & 13.1 & 1.92 & 8.60 & 1.67 \\
\hline May 1995 & 383.7 & 83.1 & 515.4 & 75.3 & 46.5 & 4.0 & 0.84 & 5.67 & 1.12 \\
\hline September 1995 & 115.9 & 9.4 & 575.6 & 104.1 & 70.5 & 11.3 & 0.80 & 4.10 & 1.45 \\
\hline
\end{tabular}

\section{Comparison between iresh and fixed nematode composition}

For evaluating the effects of formalin, Rose Bengal and the combination of both, blank absorbance was determined in all biochemical analyses (Fig. 1). All values of the different biochemical analyses are reported with standard deviations. The absorbance of formalin, Rose Bengal and formalin + Rose Bengal blanks did not show significant differences when compared with non-preserved/stained blanks (ANOVA, $F=0.44, \mathrm{~ns})$. In all cases low coefficients of variation (CV) and low absorbance values were detected (CV = $10.4,8.4$ and 8.3 for carbohydrates, proteins and lipids, respectively), so that the absorbance in nematode analyses was at least 10 times higher than in blanks. Average individual nematode biomass was $0.44 \pm$ $0.06 \mu \mathrm{g}$ DW ind. ${ }^{-1}$.

The results of the 3 biochemical analyses on fresh and fixed nematodes are shown in Fig. 2a. Mean carbohydrate contents of nematodes in the fresh and fixed

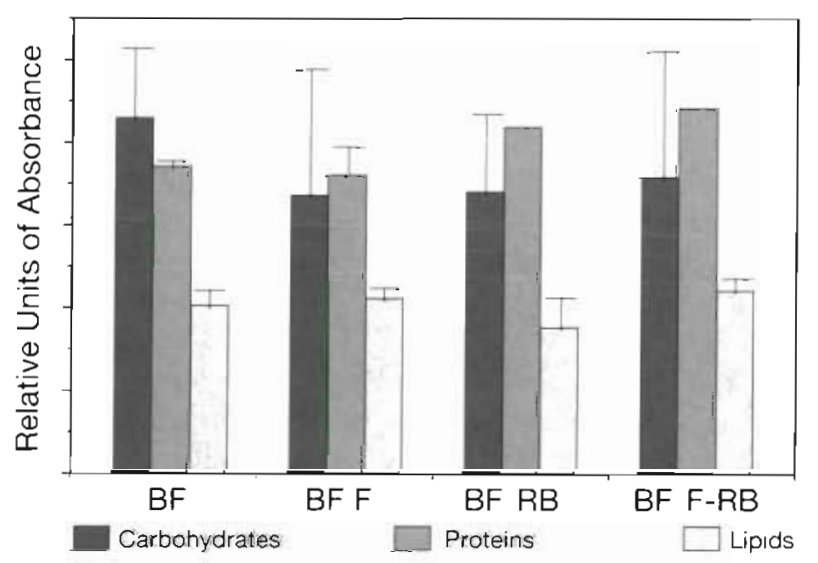

Fig. 1 Absorbance (ABS) of the untreated filter blanks (BF) and of filter blanks treated with formalin (BF F), with Rose Bengal (BF RB), and both (BF F-RB) in the determination of carbohydrates, proteins and lipids. Standard deviations are reported samples were $0.091 \pm 0.023$ and $0.117 \pm 0.013 \mu \mathrm{g}$ ind.$^{-1}$ respectively. Protein content ranged from $0.119 \pm$ $0.042 \mu \mathrm{g}$ ind. $^{-1}$ (fresh nematodes) to $0.127 \pm 0.069 \mu \mathrm{g}$ ind. $^{-1}$ (preserved nematodes). Lipid concentration on fresh nematodes was $0.068 \pm 0.034 \mu \mathrm{g}$ ind. ${ }^{-1}$, whereas the value obtained for those fixed was $0.047 \pm 0.003 \mu \mathrm{g}$ ind. $^{-1}$. Proteins accounted for 27 and $29 \%$ of DW in living and fixed nematodes; carbohydrates accounted for 21 and $26 \%$ and lipids for 15 and $11 \%$, respectively.
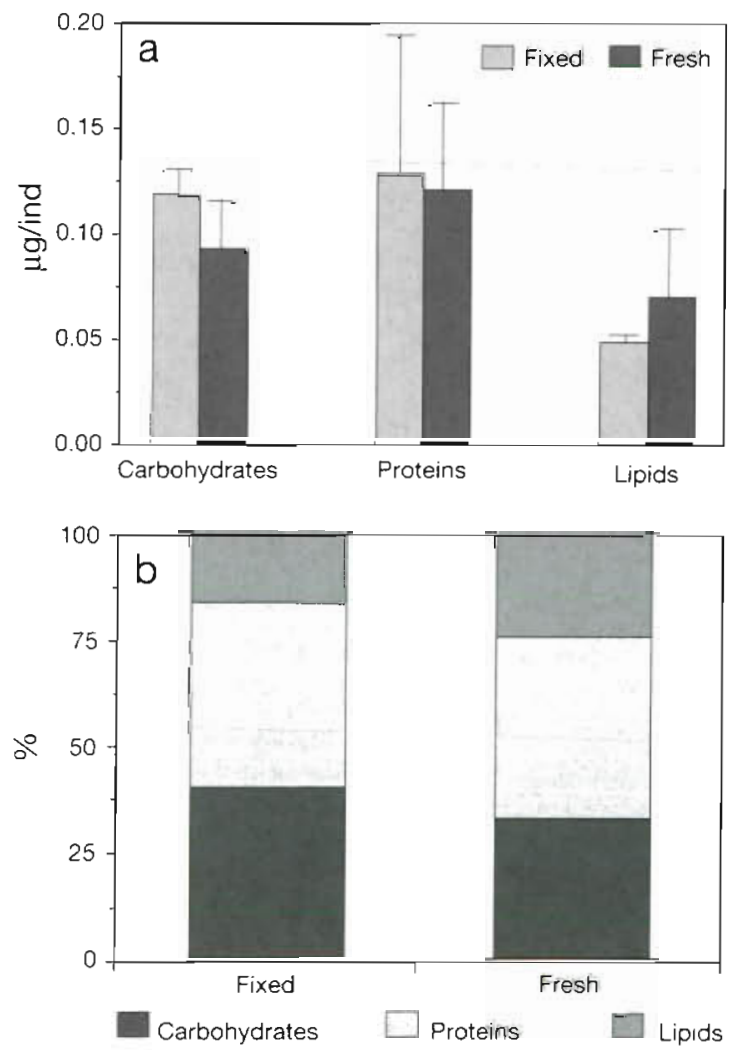

Fig. 2. Comparison between biochemical determinations in fresh and fixed coastal nematodes. (a) Carbohydrates, proteins and lipids. Standard deviations are reported; (b) comparison of the relative significance of the 3 organic classes (expressed as \%) 
None of the 3 biochemical classes of organic compounds showed significant differences between the treatments $(t$-test, $p=0.416, p=0.470$ and $p=0.333$, respectively, for carbohydrates, proteins and lipids; confidence level $5 \%$ ). As a result, the energy values of untreated and fixed nematodes were very similar (6.8 and $7.1 \times 10^{-3} \mathrm{~J}_{\text {ind }}{ }^{-1}$, respectively).

Fig. $2 \mathrm{~b}$ displays the relative significance of the 3 main biochemical classes on the nematode body composition. Proteins represented the main biochemical class, ranging from 43 to $44 \%$ of OM. Carbohydrates accounted for 33 to $40 \%$ of OM, respectively, in fresh and preserved nematodes while lipid contributed from 16 to $24 \%$ in fixed and fresh nematodes, respectively. The caloric value calculated for the body composition of the formalin-preserved coastal nematodes was $5.57 \mathrm{cal} \mathrm{mg}^{-1}$.

\section{Abundance, biomass and biochemical composition of deep-sea nematodes}

Data on abundance and individual biomass of nematodes in the deep-sea station have been summarised by Danovaro et al. (1996) and are reported in Table 2. Nematode density ranged from $56.2 \pm 9.7$ ind $10 \mathrm{~cm}^{-2}$ in August 1994 to $87.3 \pm 18.2$ ind. $10 \mathrm{~cm}^{-2}$ in September 1995. Nematode individual biomass ranged from 0.22 $\pm 0.18 \mu \mathrm{g}$ DW ind. $^{-1}$ (in September 1995) to $0.36 \pm$ $0.19 \mu \mathrm{g} \mathrm{DW}$ ind $^{-1}$ (in February 1995).

Data on seasonal changes in nematode biochemical composition are shown in Fig. 3. Protein content per individual showed the highest value in August 1994 $\left(0.109 \pm 0.015 \mu \mathrm{g}\right.$ ind $\left.^{-1}\right)$ but was constant from February to September 1995 (from $0.059 \pm 0.026$ to $0.060 \pm$ $0.018 \mu \mathrm{g}$ ind.$^{-1}$ ). Carbohydrate content per nematode displayed clear seasonal changes, with highest values in February $1995\left(0.039 \pm 0.00 \mu \mathrm{g}\right.$ ind.$\left.^{-1}\right)$ and lowest in September $1995\left(0.009 \pm 0.001 \mu \mathrm{g}\right.$ ind. $\left.{ }^{-1}\right)$. Lipid content of nematodes ranged from $0.031 \pm 0.00 \mu \mathrm{g}$ ind $^{-1}$ (in September 1995) to $0.062 \pm 0.034 \mu \mathrm{g}$ ind ${ }^{-1}$ (August 1994 and February 1995).

Fig. 4 a shows the relative significance of the 3 biochemical classes of organic compounds. Proteins were

Table 2. Temporal changes in nematode density (data relative to the top $10 \mathrm{~cm}$ of the sediments) and individual biomass

\begin{tabular}{|c|c|c|c|c|}
\hline Sampling period & $\begin{array}{l}\text { Nematode de } \\
\text { (ind. } 10 \mathrm{~cm}^{-2} \text { ) }\end{array}$ & $\begin{array}{l}\text { ensity } \\
\text { 2) SD }\end{array}$ & $\begin{array}{l}\text { Individual body } \\
\text { ( } \mu \mathrm{g} \text { DW ind. }{ }^{-1} \text { ) }\end{array}$ & $\begin{array}{l}\text { yeight } \\
\text { SD }\end{array}$ \\
\hline August 1994 & 56.2 & 9.7 & 0.32 & 0.07 \\
\hline February 1995 & 60.5 & 6.5 & 0.36 & 0.20 \\
\hline May 1995 & 78.9 & 20.2 & 0.35 & 0.06 \\
\hline September 1995 & 87.3 & 18.2 & 0.22 & 0.19 \\
\hline
\end{tabular}
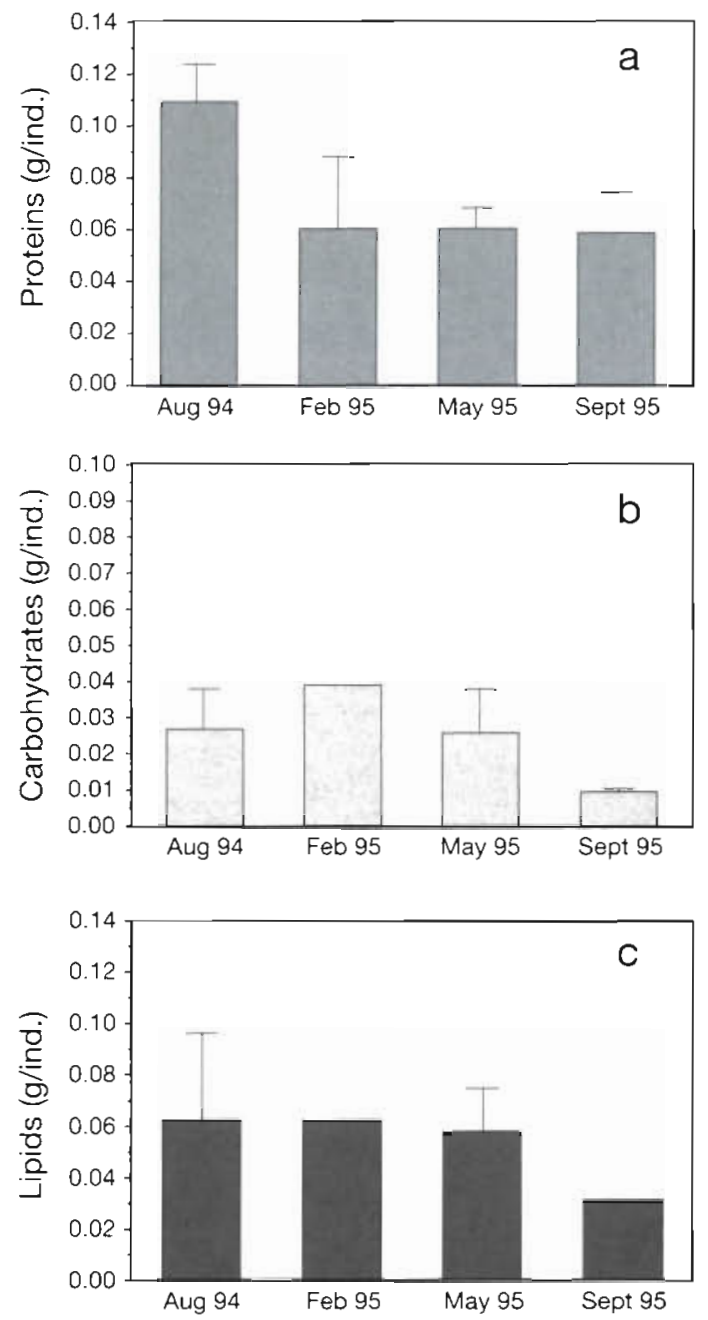

Fig. 3. Seasonal changes in the biochemical composition of deep-sea nematodes: (a) carbohydrates; (b) proteins; (c) lipids (standard deviations are reported)

the main component of OM and accounted for 38 to $60 \%$ of OM (February 1995 and September 1995, respectively). Carbohydrates represented 9 to $24 \%$ of OM (September 1995 and February 1995, respectively). Lipids accounted for 31 to $40 \%$ of OM (September 1995 and May 1995, respectively). Protein, carbohydrate and lipid accounted, on annual average, respectively for 24,8 and $17 \%$ of DW. Seasonal changes of the nematode energy content displayed a clear decrease during the sampling period, ranging from 5.5 to $2.8 \times 10^{-3} \mathrm{~J}_{\text {ind. }}{ }^{-1}$ (in August 1994 and September 1995, respectively; Fig. 4b). These data, reported for nematode density per sediment surface, indicate that the energy content of nematodes ranged from 240.6 to $324.7 \mathrm{~J} \mathrm{~m}^{-2}$ (in September and May 1995 , respectively). The caloric value of the deep-sea nematodes was $6.68 \mathrm{cal} \mathrm{mg}^{-1}$. 

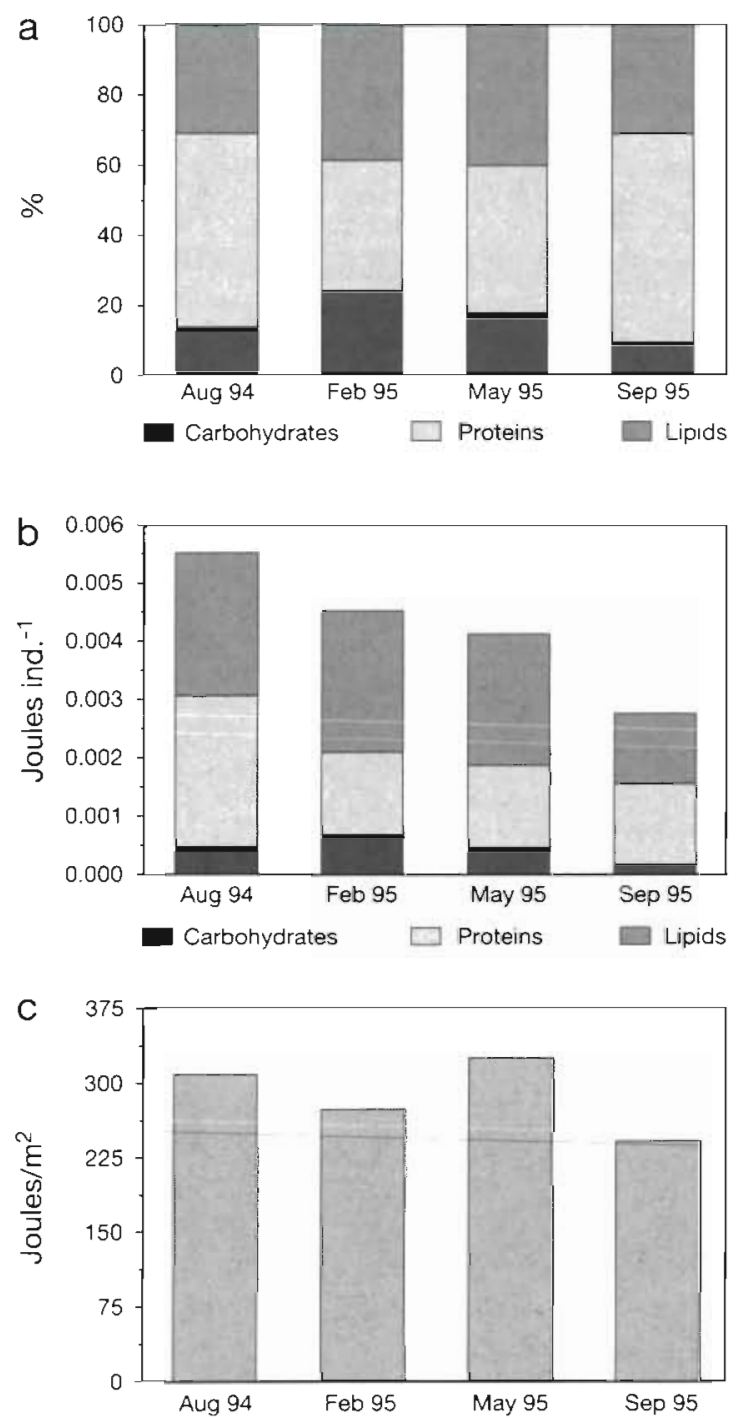

Fig. 4. Seasonal changes in the energy content of deep-sea nematodes. (a) Relative significance of the 3-biochemical classes; (b) nematode energy value; (c) energy content of nematode assemblages

\section{DISCUSSION}

\section{Effects of formalin and stain on the biochemical composition of nematodes}

The use of buffered formalin to preserve meiofaunal samples is a universally used storage technique to prevent decomposition. This, potentially, may cause analytical problems with the determination of the biochemical classes of organic compounds. Literature on the effects of preservatives on OM biochemical composition is extremely scarce (Saiz et al. 1998 and citations therein). Wakeham et al. (1993) demonstrated that results from biochemical analyses (lipids, pigments, aminoacids and carbohydrates) carried out in formalin- preserved trap samples were indistinguishable from non-preserved samples. In the present study we did not detect interference due to formalin in protein and lipid analyses. However, the analysis of carbohydrate blanks (i.e. GF/F filters with $1.0 \mathrm{ml}$ of $4 \%$ formalin) displayed higher absorbance values due to the formation of an opalescence solution. Formalin penetrated into fixed nematode is certainly lower than $4 \%$ so this effect might be negligible in their analysis. In order to avoid any formalin interference it is sufficient to rinse the filters with $10 \mathrm{ml}$ of artificial seawater (under gentle vacuum, $<80 \mathrm{~mm} \mathrm{Hg}$ ). Additional analyses on the effects of the stain revealed that the addition of Rose Bengal, in concentrations of $0.5 \mu \mathrm{g} \mathrm{ml}^{-1}$ (equivalent to the average concentration in fixed samples), did not interfere with any of the biochemical analyses (Fig. 1). Therefore, from the comparison between biochemical analyses on preserved and fresh nematodes, it is possible to conclude that the presence of formalin and Rose Bengal did not affect biochemical analysis or consequently 'the nematodes' body composition. The 3 assays that we utilised in this study are commonly applied for a wide range of natural samples (in suspended and sedimentary POM, Tselepides et al. 1996. Danovaro 1996, and sediment-trap material, Chronis et al. 1996), as well as for the determination of the biochemical composition of cultured bacteria (Fabiano \& Danovaro 1994) or in large planktonic and benthic organisms (Sertorio et al. 1985, Table 3 and citations therein). These methods are able to detect a large spectrum of chemical compounds, and are good tools in bioenergetic studies (Ansell 1974, Clarke 1977 , Goulletquer \& Wolowicz 1989, Napolitano \& Ackman 1989, Danovaro \& Fabiano 1995, Virtue et al. 1995, Chronis et al. 1996, Lehtonen 1996). However, these methods have so far only been applied to relatively large specimens (i.e. meso- and macrozooplankton and macrobenthos), and detection limit problems might arise when using very small metazoans such as nematodes. Generally, concentrations determined using these methods range from $1.5-2.0$ to $200 \mu \mathrm{g} \mathrm{ml}$. Therefore, in order to provide reliable data we collected onto the filters a number of nematodes that allowed the detection of absorbance values significantly higher than blank values. For this purpose, after preliminary tests, we selected at least 200 nematodes per filter. Also, the sensitivity of these methods (1.5 to $2.0 \mu \mathrm{g}$ ) appeared adequate for the analyses.

\section{Comparison of the biochemical composition of nematodes}

One major difference with previous studies is that, in this investigation, we determined the biochemical com- 
position of entire nematode assemblages, and not the compositon of single species. Body composition may vary both between species of the same genus and between individuals of the same species (Graeve et al. 1997, Gallagher \& Ambrose 1998). In this study we cannot evaluate the variability in body composition in the same species or between different species of nematodes. However, isolation of large numbers of nematodes of the same species is virtually impossible unless they are cultured and therefore subjected to environmental and trophic conditions clearly different from those in situ. All these factors would affect, to a large extent, the biochemical determinations.

Proteins represented the major biochemical class of organic compounds in nematodes $(43.7$ and $48.5 \%$ of $O M$ in coastal and deep-sea nematodes, respectively). Protein dominance has been observed in most studies on the biochemical composition of marine organisms (copepods, Bamstedt 1975, 1978; mysidaceans, Bamstedt 1978; euphausiids, Virtue et al. 1995; harpacticoids, Miliou et al. 1992; and bivalves, Ansell 1974). The carbohydrate content of nematodes appeared to be comparable to or higher than that of other groups, such as benthic harpacticoids, amphipods, bivalves and polychaetes (Table 3). Previous studies have reported the presence of a strong pelagic-benthic coupling between water column processes and biochemical composition of the benthic fauna (Ambrose \& Renaud 1995, Graeve et al. 1997). The main conclusion of these studies is that the composition and availability of the food sources is likely to influence also the biochemical composition of the benthic species.

In both areas investigated in this study, carbohydrates were the main biochemical class of organic compounds in the sediment, accounting for 40 to $74 \%$ of $\mathrm{OM}$ in the seagrass bed (Danovaro 1996) and for 55 to $95 \%$ in the deep-sea sediments of the Cretan Sea (Table 1). Generally, carbohydrate dominance in marine sediments is a specific feature of seagrass systems and of highly oligotrophic environments (Fabiano et al. 1995 and citations therein). Although data for comparisons are very scarce, the differences we found between nematodes and other taxa might be related to the trophic characteristics of the environment and it is possible that nematodes might change their bioenergetic strategies in response to the different quality of the OM inputs.

Generally, benthic species have relatively low lipid levels when compared to herbivorous zooplankton species (Clarke \& Peck 1991). However, body composition of nematodes revealed that lipid levels, although lower than in zooplankton, were rather high when compared to other benthic species (Table 3). The varying biochemical composition (particularly in terms of protein and lipid levels) is generally assumed to be the

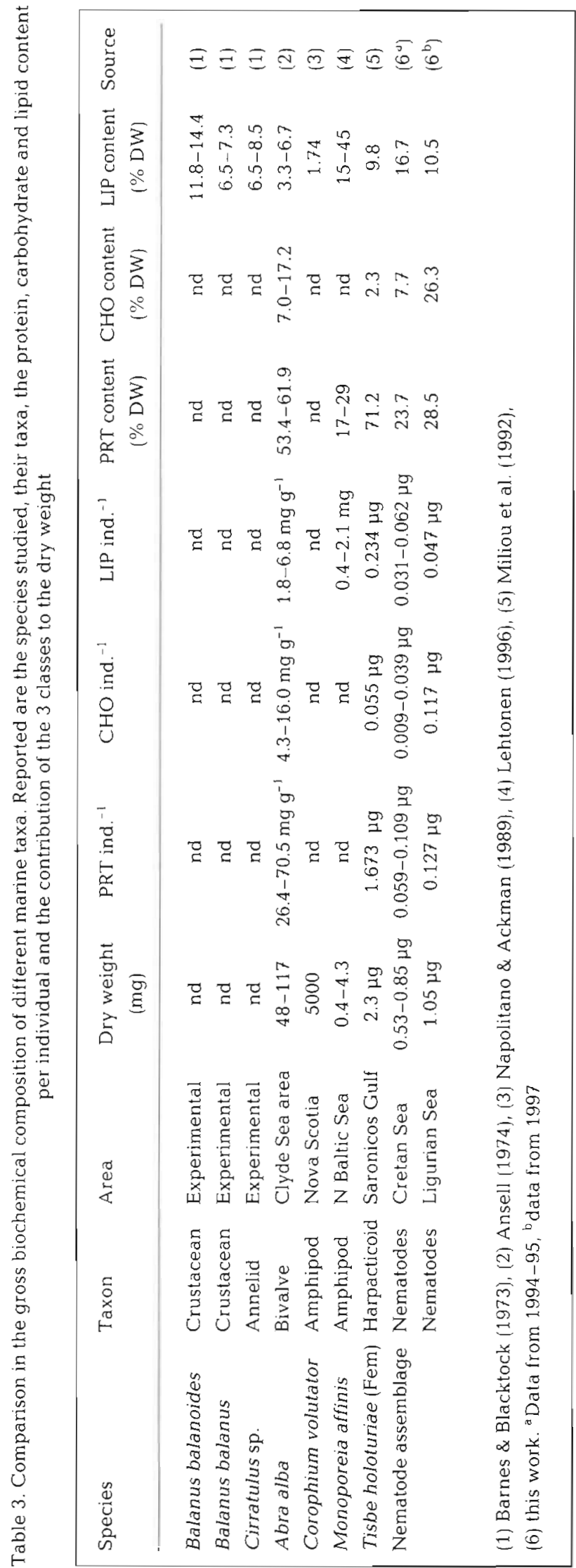


result of different bioenergetic strategies in populations inhabiting different environments (Lehtonen 1996). Lipid accumulation is the most widespread long-term energy storage strategy in aquatic crustaceans and their reproductive potential is largely dictated by lipid content (Sargent \& Henderson 1986). In this study, we found significant differences between coastal and deep-sea nematodes in terms of lipid levels, with higher lipid concentrations in deep-sea specimens $(11 \pm 1.4$ vs $17 \pm 1.9 \%$ of $D W$, respectively; $t$-test, $t=18.6, \mathrm{p}<0.01$ ). The nourishment of deep-sea benthic organisms is largely dependent on the inputs of primary organic matter from the photic layer, whose quality and quantity vary widely throughout the year (Rice et al. 1994). Previous studies suggested that organisms from regions characterised by highly variable food inputs must have efficient energy storage systems to enable them to cope with long periods of very low food availability (Lee \& Hirota 1973, Lee 1975, Sargent \& Whittle 1981). The differences in lipid level between coastal and deep-sea nematodes might find similar explanations, especially if we take into account the extremely oligotrophic conditions of the deep Cretan Sea. Bioenergetic strategies similar to those hypothesised here for deep-sea nematodes have been reported for open-sea deposit-feeding amphipods from the northern Baltic Sea (lipid level ranging from 15 to $45 \%$ of DW; Lehtonen 1996) and for other deep-sea species living at high latitudes (e.g. in the Arctic; Clarke 1983, Sargent \& Henderson 1986).

Generally, deep-sea sediments are characterised by very low temperatures; thus discriminating between the relative importance of temperature and variability of the food inputs in determining body composition, and particularly lipid content, is often difficult. Littlepage (1964), who examined Antarctic planktonic crustaceans, gave evidence for an increase in total lipid content with decreasing water temperature. Jeffries (1979), comparing plankton samples collected in Antarctica and in the Gulf of Mexico, provided further evidence for the increase of lipid content with decreasing water temperature. Our study was carried out in the Mediterranean Sea, which is characterised by high deep-water and sediment temperatures $\left(>13.0^{\circ} \mathrm{C}\right)$ throughout the year. The deep-sea sediments sampled in this study, displayed temperatures very close to those reported in the seagrass bed of the Ligurian Sea (where coastal samples were taken) during spring $\left(-14.0^{\circ} \mathrm{C}\right)$. This indicates that the differences in lipid content observed between coastal and deep-sea nematodes are unlikely to be dependent upon temperature. Our data support the hypothesis that nematodes from the oligotrophic deep Cretan Sea increased their lipid content in order to cope with long periods of very poor food conditions.

\section{Seasonal changes in the biochemical composition of deep-sea nematodes}

Benthic communities inhabiting shallow water depths are closely coupled to seasonal changes in food supply (Graf 1992), but pelagic-benthic coupling in deep-sea environments is still supported by relatively little evidence (Gooday 1988, Tietjen et al. 1989, Wassmann et al. 1996). Some nematode species are known to react to the seasonal deposition of phytodetritus in certain deep-sea areas (Thiel et al. 1988, 1989), but several authors failed in identifying meiofaunal response to depositional events in the deep-sea sediments of the Porcupine Abyssal Plain (North Atlantic) (Pfannkuche 1993, Gooday et al. 1996). Previous studies in the Cretan Sea showed the presence of very low primary production values and limited seasonal changes with highest values in late winter (annual average $162 \mathrm{mg} \mathrm{C} \mathrm{m}^{-2} \mathrm{~d}^{-1}$, Psarra et al. 1996). Moreover, particle fluxes were extremely low throughout the year (annual mass flux: $209 \mathrm{mg} \mathrm{m}^{-2}$ $\mathrm{d}^{-1}$, Chronis et al. 1996). These conditions are possibly responsible for the lack of any meiofaunal density response to pelagic inputs (Danovaro et al. 1996). In our study nematode body weight decreased between February-March and September 1995 in relation with the decrease in particle fluxes. This result is in agreement with previous studies, reporting that changes of body weight are dependent upon seasonal fluctuations in food availability and temperature (Ansell 1974). Tietjen et al. (1989) observed a highly significant relationship between organic flux rates and nematode biomass. Soetaert et al. (1997) pointed out the tendency of nematode individual weight to decrease with depth (and therefore with reduced food availability). Similarly we found higher nematode individual weight in coastal sediments (rich in OM) than in the food limited deep-sea $(0.44 \pm 0.06$ vs $0.37 \pm 0.06 \mu \mathrm{g} \mathrm{DW}$ ind $^{-1}$, respectively). Moreover, the significant relationship between individual body weight and carbohydrate fluxes (Spearman-Rank correlation: $r=0.94, p=0.02$ ) might indicate the presence of a coupling between deep-sea nematode size and particle fluxes.

Other authors have suggested that seasonal changes in body weight influenced the biochemical composition and calorific content of the tissues, and investigated the tendency of the calorific value to increase with the dry weight (i.e. size) of the organism (Norrbin \& Bamstedt 1984). From the analyses of nematode assemblages we obtained results in contrast with this hypothesis. In fact, despite the higher biomass of the coastal nematodes, we observed clearly higher caloric values in the deep-sea nematodes $\left(6.68 \pm 0.11\right.$ vs $5.57 \pm 0.04 \mathrm{cal} \mathrm{mg}^{-1}$, in deep-sea 
and coastal nematodes, respectively, $t$-test, $t=26.63$, $\mathrm{p}<0.01)$

Generally, different caloric values reflect biochemical differences in body composition and particularly lower lipid level in low-energy animals. Norrbin \& Bamstedt (1984) analysed 12 taxonomic groups and reported higher energy values for planktonic than for benthic organisms. The mean values they obtained for the 12 investigated groups (5.697 $\mathrm{cal} \mathrm{mg}^{-1}$ ) is very close to the one observed for coastal nematodes in this study (5.57 cal $\mathrm{mg}^{-1}$ ) and to the most probable value in organisms (Pruus 1970). Conversely, caloric values reported for deep-sea nematodes are closer to those reported for planktonic and/or high latitude organisms (Clarke 1983, Clarke \& Peck 1991). Due to their intermediate trophic position (i.e. between organic detritus and macrofaunal meiofauna can play a key role in the energy transfer within benthic food webs. As nematodes largely dominate meiofaunal assemblages in most marine environments and particularly in the deep sea, their high caloric value indicates that they might represent an important high-quality food source for higher trophic levels.

The quality and quantity of food arriving at the benthos are undoubtedly important in determining the body composition of benthic organisms but have received little attention (Gallagher \& Ambrose 1998). Fluctuations in food availability are known to play an important role in controlling copepod populations (Dagg 1977. Davis \& Alatalo 1992). Other studies have demonstrated that phytoplankton blooms induce the increase of the lipid concentrations in herbivores (e.g. Euchaeta antartica, Metridia longa, Calanus hyperboreas; Littlepage 1964, Lee et al. 1972, Kattner et al. 1981) and influence production cycles and therefore body composition in the euphausiid Thysanoessa inermis (Falk-Petersen 1981).

In the deep Cretan Sea, particle fluxes displayed seasonal changes with a clear reduction of the food inputs (especially carbohydrates and proteins) from February to September 1995. Sedimentary organic matter concentration, individual nematode energy content and biomass reflected this trend. When the energy content of nematodes is normalised to nematode density $\mathrm{m}^{-2}$, the seasonal changes in total energy content (expressed in $\mathrm{J} \mathrm{m}^{-2}$ ) is smaller (Fig. 4c). This might results from the apparent balance between diminished size and energy content and the slight increase in nematode density, reported between February and September 1995

Although further studies are needed to draw definitive conclusions, the analysis of the biochemical composition of nematodes seems to be a promising tool to investigate pelagic-benthic coupling, bioenergetic strategies and trophic relevance of this component in marine ecosystems.
Acknowledgements. This work was carried out in the frame of the MTP Programme CINCS: 'Pelagic-benthic coupling in the Oligotrophic Cretan Sea' and financially supported by EC funding under contract No. MAS2-CT94-0092. The authors are indebted to Prof. N. Della Croce (ISAM, University of Genoa) for providing the opportunity to carry on his work, Dr Tselepides and Prof. Eleftheriou (IMBC, Crete, Greece) for help during sampling and providing laboratory facilities and to 3 anonymous referees for improving the quality of the manuscript.

\section{LITERATURE CITED}

Ambrose WG, Renaud PE (1995) Benthic response to water column productivity patterns: evidence for benthicpelagic coupling in the Northeast Water Polynya. J Geophys Res 110:4411-4421

Ansell AD (1974) Seasonal changes in biochemical composition of the bivalve Albra alba from the Clyde Sea area Mar Biol 25:13-20

Bamstedt $U$ (1975) Studies on the deep-water pelagic community of Korsfjorden, Western Norway: ecological aspects of individual variations in weight and protein and lipid content of Euchaeta norvegica (Copepoda). Sarsia 59:31-46

Bamstedt U (1978) Studies on the deep-water pelagic community of Korsfjorden, Western Norway: seasonal variation in weight and biochemical composition of Chiridius armatus (Copepoda), Boreomysis arctica (Mysidacae), and Eukrohnia hamata (Chaetognatha) in relation to their biology. Sarsia 63:145-154

Barnes H, Blackstock J (1973) Estimation of lipids in marine animals and tissues: detailed investigation of the sulphophosphovanillin method for 'total' lipids. J Exp Mar Biol Ecol 12:103-118

Bell SS, Coull BC (1978) Field evidence that shrimp predation regulates meiofauna. Oecologia 35:141

Bligh EG, Dyer W (1959) A rapid method for total lipid extraction and purification. Can J Biochem Physiol 37:911-917

Christensen $H_{4}$ Kanneworff E (1985) Sedimenting phytoplankton as major food source for suspension and deposit feeders in the Øresund. Ophelia 24:223-244

Chronis G, Stavrakakis S, Danovaro R, Tselepides A, Wassmann P, Duineveld G, Della Croce N, Karageorgis A, Zivanovic S, Ypma JE, Dell'Anno A, Marrale D, Martorano D, Kabouri G, Pagou K (1996) Downward fluxes. CINCS: Pelagic-benthic coupling in the oligotrophic Cretan Sea. In: Tselepides A, Papadopoulou KN, Polychronaki T (eds) MAST II, Mediterranean targeted project final report. Final Reports, Heraklion, Greece, p 82-112

Clarke A (1977) Seasonal variations in the total lipid content of Chorismus antarcticus (Pfeffer) (Crustacea: Decapoda) at South Georgia. J Exp Mar Biol Ecol 27:93-106

Clarke A (1983) Life in cold water the physiological ecology of polar marine ectotherms. Oceanogr Mar Biol Annu Rev 21:341-453

Clarke A, Peck LS (1991) The physiology of polar marine zooplankton. In: Sakshaug E, Hopkins CCE, Otistland NA (eds) Proceedings of the Pro Mare Symposium on polar marine ecology. Polar Res 10:355-369

Coull BC, Bell SS (1979) Perspectives of marine meiofaunal ecology. In: Livingston RJ (ed) Ecological processes in coastal and marine ecosystems. Plenum Publishing Company, New York

Dagg $M$ (1977) Some effects of patchy food environment on copepods. Limnol Oceanogr 22:99-108 
Danovaro R (1996) Detritus-bacteria-meiofauna interactions in a seagrass bed (Posidonia oceanica) of the NW Mediterranean. Mar Biol 127:1-13

Danovaro R, Fabiano M (1995) Seasonal and interannual variation of benthic bacteria in a seagrass bed of the Mediterranean Sea: relationships with labile organic compounds and other environmental factors. Aquat Microb Ecol 9: $17-26$

Danovaro R, Tselepides A, Della Croce N, Otegui A, Dell'Anno A, Ferrando M, Martorano D (1996) Meiofaunal community structure of the continental shelf, slope and deep-sea basin of the Cretan Sea. CINCS: Pelagic-benthic coupling in the oligotrophic Cretan Sea. In: Tselepides A, Papadopoulou KN, Polychronaki T (eds) MAST II, Mediterranean targeted project final report. Final Report, Heraklion, Greece, p 157-166

Davis CS, Alatalo P (1992) Effects of constant and intermittent food supply on life-history parameters in a marine copepod. Limnol Oceanogr 17:1618-1639

Dubois M, Gilles KA, Hamilton JK, Rebers PA, Smith F (1956) Colorimetric method for determination of sugars and related substances. Andl Chem 28:350-356

Fabiano M, Danovaro R (1994) Composition of organic matter in sediments facing a river estuary (Tyrrhenian Sea): relationships with bacteria and microphytobenthic biomass. Hydrobiologia 277:71-84

Fabiano M, Danovaro R, Fraschetti S (1995) Temporal trends analysis of the elemental and biochemical composition of the sediment organic matter in subtidal sandy sediments of the Ligurian Sea (NW Mediterranean): a three year study. Cont Shelf Res 15:1453-1469

Falk-Petersen S (1981) Ecological investigations on the zooplankton community of Balsfjorden, Northern Norway: seasonal changes in body weight and the main biochemical composition of Thysanoessa inermis (Kroyer), T. raschi (M. Sars), and Meganyctiphanes norvegica (M. Sars) in relation to environmental factors. J Exp Mar Biol Ecol 49: $103-120$

Folch J, Lees M, Stanley GHS (1957) A simple method for the isolation and purification of total lipides from animal tissues. J Biol Chem 226:497-509

Gallagher ML, Ambrose WG (1998) Comparative studies in biochemical composition of benthic invertebrates (bivalves, ophiuroids) from the Northeast Water (NEW) Polynya. Polar Biol 19:167-171

Gerchakov SM, Hatcher PG (1972) Improved technique for analysis of carbohydrates in sediments. Limnol Oceanogr $17: 938-943$

Gooday AJ (1988) A response by benthic Foraminifera to the deposition of phytodetritus in the deep-sea. Nature 332 : $70-73$

Gooday AJ, Pfannkuche O, Lambshead PJD (1996) An apparent lack of response by metazoan meiofauna to phytodetritus deposition in the bathyal north-eastern Atlantic. J Mar Biol Assoc UK 76:2297-2310

Goulletquer P, Wolowicz M (1989) The shell of Cardium edule, Cardium glaucum and Ruditapes philippinarum: organic content, composition and energy value, as determined by different methods. J Mar Biol Assoc UK 69:563-572

Graeve M, Kattner G, Piependurgo D (1997) Lipids in Arctic benthos: does the fatty acid and alcohol composition reflect feeding and trophic interactions? Polar Biol 18:53-61

Graf G (1992) Benthic-pelagic coupling: a benthic view. Ocean Mar Biol Ann Rev 30:149-190

Hartree EF (1972) Determination of proteins: a modification of the Lowry method that gives linear photometric response. Anal Biochem 48:422-427
Higgins RP, Thiel H (1988) Introduction to the study of meiofauna. Smithsonian Institution Press, Washington, DC

Hopkins CCE, Sargent JR, Nilssen EM (1993) Total lipid content, and lipid and fatty acid composition of the deepwater prawn Pandalus borealis from Balsfjord, northern Norway: growth and feeding relationships. Mar Ecol Prog Ser 96:217-228

Ignatiades L (1998) The productive and optical status of the oligotrophic waters of the Southern Aegean Sea (Cretan Sea), Eastern Mediterranean. J Plankton Res 20:985-995

Jeffries (1979) Biochemical correlates of seasonal changes in marine communities. Am Nat 113:643-658

Kattner G, Krause M, Trahms J (1981) Lipid composition of some typical North Sea copepods. Mar Ecol Prog Ser 4: $69-74$

Lee RF (1975) Lipids in arctic zooplankton. Comp Biochem Physiol 51B:263-266

Lee RF, Hirota J (1973) Wax esters in tropical zooplankton and nekton and geographical distribution of wax esters in marine copepods. Limnol Oceanogr 18:227-239

Lee RF, Nevenzel JC, Paffenhofer GA (1972) The presence of wax esters in marine planktonic copepods. Naturwissenschaften 59:406-411

Lehtonen KK (1996) Ecophysiology of the benthic amphipod Monoporeia affinis in an open-sea area of the northern Baltic Sea: seasonal variations in body composition, with bioenergetic considerations Mar Ecol Prog Ser 143: $87-98$

Littlepage JL (1964) Seasonal variation in lipid content of two antarctic marine Crustacea. Actual Sci Ind 1312: $4663-4700$

Marsh JB, Weinstein WJ (1966) A simple charring method for determination of Lipids. J Lipid Res 7:574-576

Miliou H, Moraitou-Apostopoulu M, Argyridou M (1992) Biochemical composition of Tisbe holothuriae (Copepoda: Harpacticoida) and its differentiation in relation to developmental stages. Ophelia 36:159-166

Montagna PA, Blanchard GF, Dinet A (1995) Effect of production and biomass of intertidal microphytobenthos on meiofaunal grazing rates. J Exp Mar Biol Ecol 185:149-165

Napolitano GE, Ackman RG (1989) Lipids and hydrocarbons in Corophium volutator from Minas Basin, Nova Scotia. Mar Biol 100:333-338

Norbbin F, Bamstedt U (1984) Energy content in benthic and planktonic invertebrates of Kosterjorden, Sweden. A comparison of energetic strategies in marine organism groups Ophelia 23:47-64

Pfannkuche $O$ (1993) Benthic response to sedimentation of particulate organic matter at the BIOTRANS station $47^{\circ} \mathrm{N}$, $20^{\circ} \mathrm{W}$. Deep-Sea Res 40:135-149

Pickney J, Sandulli R (1990) Spatial autocorrelation analysis of meiofaunal and microalgal populations on an intertidal sand flat: scale linkage between consumers and resources. Estuar Coast Shelf Sci 30:341-353

Pruus I (1970) Calorific values as an element of bioenergetic investigations. Pol Arch Hydrobiol 17:183-199

Psarra S, Tselepides A, Ignatiades L, Dafnomili E (1996) Primary production estimates in the Cretan Sea. CINCS: Pelagic-benthic coupling in the oligotrophic Cretan Sea In: Tselepides A, Papadopoulou KN, Polychronaki T (eds) MAST II, Mediterranean targeted project final report. Final Report, Heraklion, Greece, p 46-52

Rice AL, Thurston MH, Bett BJ (1994) The IOSDL DEEPSEAS programme: photographic evidence for the presence and absence of seasonal input of phytodetritus at contrasting abyssal sites in the north-eastern Atlantic Ocean. DeepSea Res 41:1305-1320 
Riera P, Richard P, Grémare A, Blanchard G (1996) Food source of intertidal nematodes in the Bay of MarennesOléron (France), as determined by dual stable isotope analysis. Mar Ecol Prog Ser 142:303-309

Saiz E, Fara A, Berdalet E (1998) RNA content of copepods as a tool for determining adult growth rates in the field Limnol Oceanogr 43:465-470

Sargent JR, Henderson RJ (1986) Lipids. In: Corner EDS, O'Hara SCM (eds) The biological chemistry of marine copepods. Clarendon Press, Oxford, p 59-108

Sargent JR, Whittle K (1981) Lipids and hydrocarbons in the marine food web. In: Longhurst AR (ed) Analysis of marine ecosystems. Academic Press, London, p 491-533

Sertorio T, Cassiani L, Palmero P (1985) Biochemical composition of zooplankton in coastal waters (Ligurian Sea) Mem Biol Mar Oceanogr 15:91-113

Soetaert K. Heip C (1995) Nematode assemblages of deep-sea and shelf break sites in the North Atlantic and Mediterranean Sea. Mar Ecol Prog Ser 125:171-183

Soetaert K, Vanaverbeke J, Heip C, Herman PMJ, Middelburg JJ, Sandee A, Duineveld G (1997) Nematode distribution in ocean margin sediments of the Goban Spur (northeast Atlantic) in relation to sediment geochemistry. Deep-Sea Res 44:1671-1683

Soyer J (1985) Mediterranean Sea meiobenthos. In: MoraitouApostopoulou $M$, Kiortis $V$ (eds) Mediterranean marine ecosystems. Plenum Publishing Corporation, New York, p 85-108

Thiel H, Pfannkuche O, Schriever G, Lochte K, Gooday AJ, Hemleben $C$, Mantoura RFC, Turley ( $M$, Patching JW, Rieman F (1988/1989) Phytodetritus on the deep-sea floor of a central oceanic region of the north east Atlantic. Biol Oceanogr 6:203-239

Tietjen JH (1992) Abundance and biomass of metazoan meiobenthos in the deep sea. In: Rowe GT, Pariente $V$ (eds)

Editorial responsibility: Otto Kinne (Editor),

Oldendorf/Luhe, Germany
Deep-sea food chains and the global carbon cycle. KJuwer Academic Publishers, Dordrecht, p 45-62

Tietjen JH, Deming JW, Rowe GT, Macko S, Wilke RJ (1989) Meiobenthos of the Hatteras Abyssal plain and Puerto Rico trench: abundance, biomass and associations with bacteria and particulate fluxes. Deep-Sea Res 36: $1567-1577$

Tselepides A, Danovaro $R$, Della Croce $N$, Duineveld $G$, Polychronaki $T$, Dell'Anno A, Dafnomili E, Plaiti W, Akumianaki G, Martorano D (1996) Seasonal variability of chloroplastic pigment, IOC, TON, ATP and labile organic matter (carbohydrates, lipids, proteins and nucleic acids) over the continental margin and deep-sea sediments of the oligotrophic Cretan Sea. CINCS: Pelagic-benthic coupling in the oligotrophic Cretan Sea. In: Tselepides A, Papadopoulou KN, Polychronaki T (eds) MAST Il, Mediterranean targeted project final report. Final Report, Heraklion, Greece, p 113-134

Vincx $M$, Bett BJ, Dinet A, Ferrero $T$, Gooday AJ, Lambshead PJD, Pfannkuche $O$, Soltwedel T, Vanreusel A (1994) Meiobenthos of the deep Northeast Atlantic: a review. Adv Mar Biol 30:1-18

Virtue P, Johannes RE, Nichols PD, Young JW (1995) Biochemical composition of Nyctiphanes australis and its possible use as an aquaculture feed source: lipids, pigments and fluoride content. Mar Biol 122:121-128

Wakeham SG, Hedges JI, Lee C, Pease TK (1993) Effect of poison and preservatives on the composition of organic matter in a sediment trap experiment. J Mar Res 51: $669-696$

Wassmann P, Andreassen I, Reigstad M, Slagstd D (1996) Pelagic-benthic copling in the Nordic Seas: the role of episodic events. PSZN I: Mar Ecol 17:447-471

Winberg GG (1971) Methods for the estimation of production of aquatic animals. Academic Press, London

Submitted: July 28, 1998; Accepted:December 1, 1998 Proofs received from author(s): March 29, 1999 